14. Ham RG, St Clair J, Meyer S. Improved media for rapid clonal growth of normal human skeletal muscle satellite cells. In: Griggs RC, Karpati G, eds. Myoblast transfer therapy. New York: Plenum Press, 1990:193-199.

15. Schubert W, Zimmermann K, Cramer M, Starzinski-Powitz A. Lymphocyte antigen Leu 19 as a molecular marker of regeneration in human skeletal muscle. Proc Natl Acad Sci USA 1989;86:307-311.

16. Baron P, Constantin G, D'Andrea A, et al. Production of tumor necrosis factor and other proinflammatory cytokines by human mononuclear phagocytes stimulated with myelin P2 protein. Proc Natl Acad Sci USA 1993;90:4414-4418.

17. Meda L, Baron P, Prat E, et al. Proinflammatory profile of cytokine production by human monocytes and murine microglia stimulated with $\beta$-amyloid [25-35]. J Neuroimmunol 1999;93:45-52.

18. Akira S, Hirano T, Taga T, Kishimoto T. Biology of multifunctional cytokines: IL- 6 and related molecules (IL-1 and TNF). FASEB J 1990;4:2860-2867.

19. Jordan M, Otterness IG, Ng R, Gessner A, Rollinghoff M, Beuscher HU. Neutralization of endogenous IL-6 suppresses induction of IL-1 receptor antagonist. J Immunol 1995;154: 4081-4090.

20. Bartoccioni E, Michaelis D, Hohlfeld R. Constitutive and cytokine-induced production of interleukin- 6 by human myoblasts. Immunol Lett 1994;42:135-138.

21. Gallucci S, Provenzano C, Mazzarelli P, Scuderi F, Bartoccioni E. Myoblasts produce IL-6 in response to inflammatory stimuli. Int Immunol 1998;10:267-273.

22. Meda L, Bernasconi S, Bonaiuto C, et al. $\beta$-amyloid [25-35] peptide and IFN- $\gamma$ synergistically induce the production of the chemotactic cytokine MCP-1/JE in monocytes and microglial cells. J Immunol 1996;157:1213-1218.

23. Askanas V, Sarkozi E, Bilak M, Alvarez RB, Engel WK. Human muscle macrophages express $\beta$-amyloid precursor and prion proteins and their mRNAs. Neuroreport 1995;6:1045-1049.

24. Askanas V, Engel WK. Newest approaches to diagnosis and pathogenesis of sporadic inclusion-body myositis and hereditary inclusion-body myopathies, including molecularpathologic similarities to Alzheimer disease. In: Askanas V, Serratrice G, Engel WK, eds. Inclusion-body myositis and myopathies. Cambridge: Cambridge University Press, 1998:3-78.

25. Askanas V, Alvarez RB, Engel WK. $\beta$-Amyloid precursor epitopes in muscle fibers of inclusion body myositis. Ann Neurol 1993;34:551-560.

26. Askanas V, Engel WK. Does overexpression of $\beta$ APP in aging muscle have a pathogenic role and relevance to Alzheimer's disease? Clues from inclusion body myositis, cultured human muscle, and transgenic mice. Am J Pathol 1998;153:16731677.

27. Renauld JC, Vink A, Van Snick J. Accessory signals in murine cytolytic T cell responses. Dual requirement for IL-1 and IL-6. J Immunol 1989;143:1894-1898.

28. Mantegazza R, Bernasconi P, Confalonieri P, Cornelio F. Inflammatory myopathies and systemic disorders: a review of immunopathogenetic mechanisms and clinical features. J Neurol 1997;244:277-287.

29. Ebisui C, Tsujinaka T, Morimoto T, et al. Interleukin-6 induces proteolysis by activating intracellular proteases (cathepsins B and L, proteasome) in $\mathrm{C} 2 \mathrm{C} 12$ myotubes. Clin Sci (Colch) 1995;89:431-439.

\title{
Neuro/mages
}
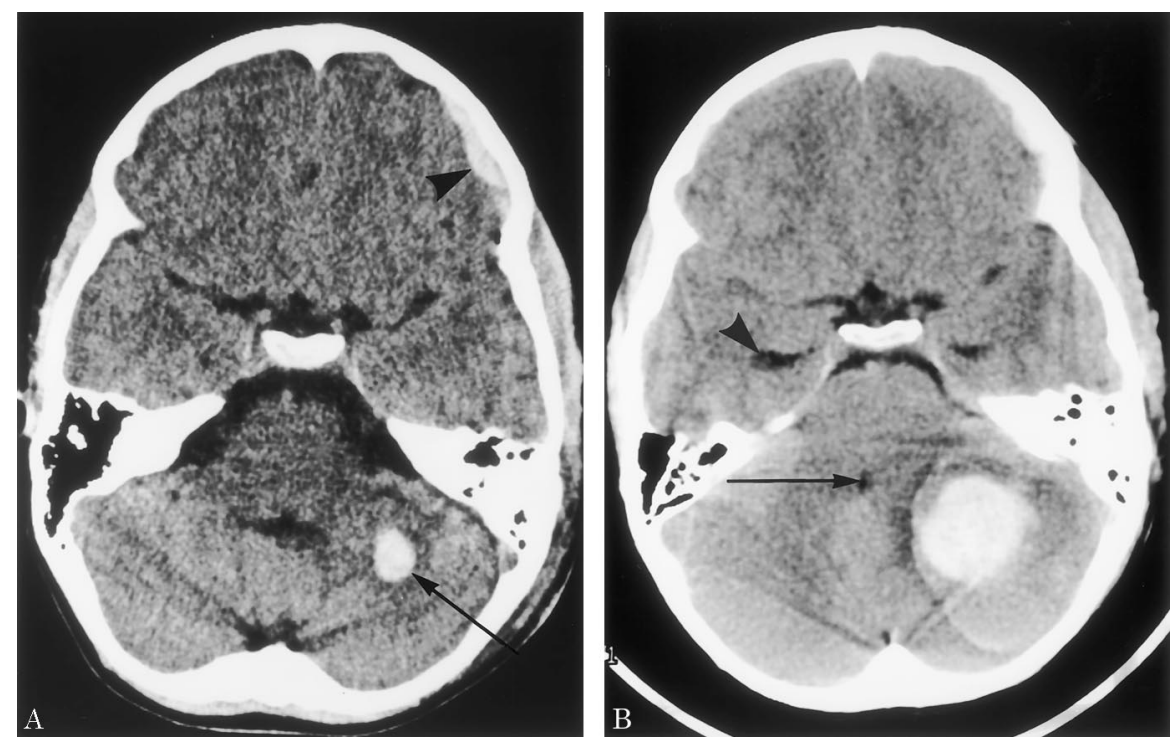

Figure. (A) There is a small frontal extradural hematoma (arrowhead) and a 0.5-mL hematoma in the left cerebellar hemisphere (arrow). (B) Dramatic expansion of the cerebellar hematoma and surrounding edema have nearly obliterated the fourth ventricle (arrow). Dilatation of the lateral ventricular temporal horns (arrowhead) indicates obstructive hydrocephalus.

\section{Evolving traumatic cerebellar hematoma}

Andrew J. Martin, FRCS, Nicholas W.M. Thomas, FRCS, London, UK

A 10-year-old boy fell from a tree onto concrete. When he was first assessed, he had a headache but had a normal conscious level and no neurologic signs. A cranial CT scan was performed 5 hours after the injury (figure, A). He remained alert, neurologically intact, and cardiovascularly stable for a further 24 hours, but then deteriorated with worsening headache, drowsiness, neck retraction, and left hemiparesis. After a repeated CT scan (see the figure, B) the cerebellar hematoma was evacuated. He recovered completely. Such late delayed expansion of a traumatic intracerebral hematoma is unusual. ${ }^{1}$ Possible mechanisms include coagulopathy (absent in this case) and local vascular necrosis or dysautoregulation. ${ }^{2}$

1. Yamaki T, Hirakawa K, Ueguchi T, Tenjin H, Kuboyama T, Nakagawa Y. Chronological evaluation of acute intracerebral haematoma. Acta Neurochir (Wien) 1990;103:112-115.

2. Gudeman SK, Kishore PRS, Miller JD, Girevendulis AK, Lipper MH, Becker DP. The genesis and significance of delayed traumatic intracerebral hematoma. Neurosurgery 1979;5:309-313. 


\title{
Neurology
}

\author{
Evolving traumatic cerebellar hematoma
}

Andrew J. Martin and Nicholas W.M. Thomas

Neurology 2001;57;1565

DOI 10.1212/WNL.57.9.1565

This information is current as of November 13, 2001

\section{Updated Information \& Services}

\section{References}

Subspecialty Collections

Permissions \& Licensing

Reprints

\section{including high resolution figures, can be found at:} http://n.neurology.org/content/57/9/1565.full

This article cites 2 articles, 0 of which you can access for free at: http://n.neurology.org/content/57/9/1565.full\#ref-list-1

This article, along with others on similar topics, appears in the following collection(s):

\section{Brain trauma}

http://n.neurology.org/cgi/collection/brain_trauma

\section{CT}

http://n.neurology.org/cgi/collection/ct

Intracerebral hemorrhage

http://n.neurology.org/cgi/collection/intracerebral_hemorrhage

Information about reproducing this article in parts (figures,tables) or in its entirety can be found online at:

http://www.neurology.org/about/about_the_journal\#permissions

Information about ordering reprints can be found online: http://n.neurology.org/subscribers/advertise

Neurology ${ }^{\circledR}$ is the official journal of the American Academy of Neurology. Published continuously since 1951, it is now a weekly with 48 issues per year. Copyright . All rights reserved. Print ISSN: 0028-3878.

Online ISSN: 1526-632X.

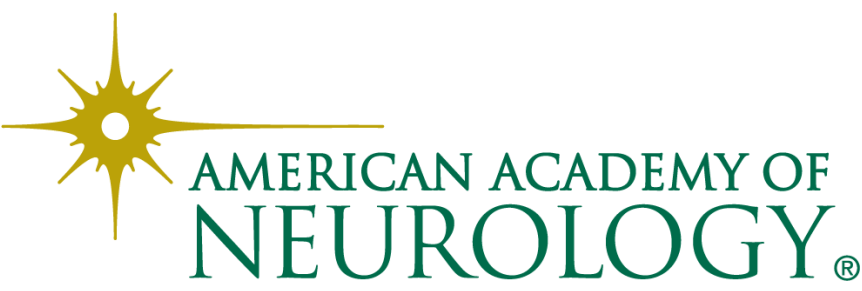

